\title{
ОБЗОР СОСТОЯНИЯ ПРОИЗВОДСТВА И ПОТРЕБЛЕНИЯ БАРИТОВОГО СЫРЬЯ В РОССИИ
}

\author{
Боярко Григорий Юрьевич 1 , \\ gub@tpu.ru
}

\author{
Хатьков Виталий Юрьевич 1,2 , \\ V.Khatkov@adm.gazprom.ru \\ 1 Национальный исследовательский Томский политехнический университет, \\ Россия, 634050, г. Томск, пр. Ленина, 30. \\ 2 ПАО «Газпром», \\ Россия, 196143, г. Санкт-Петербург, пл. Победы, 2.
}

\begin{abstract}
Актуальность работы обусловлена наличием периодической импортозависимости России по баритовому сырью. Цель: изучение динамики товарных потоков (производства, импорта, экспорта, потребления) баритового сырья в России и в мировом масштабе, его цен (мировых и российских), сырьевой базы барита России и перспектив ее национального производства. Методы: статистический, графический, логический.

Результаты. На основании анализа имеющейся информации сделан вывод, что баритовое минеральное сырье в России является критическим товарным продуктом ввиду ограниченности его добычи на единственном месторождении и наличия значимых объемов импорта барита на границе порога импортозависимости. Мальй размер российского импортного товарного потока барита, с одной стороны, легко обеспечивается, с другой - не способен влиять на цены и объемы торговых экспортно-импортных потоков баритового сырья. Предложены меры регулирования баритодобывающей отрасли: возобновление добычных работ на Хойлинской группе баритовых месторождений (Хойлинское, Малохойлинское и Пальникское) в Республике Коми и на техногенном Урском месторождении в Кемеровской области; организация оценочных и разведочных работ на Кутень-Булукском, Моховском, Карасугском-ІІ и Юбилейном месторождениях к северу от выбывающего из эксплуатации Толчеинского месторождения в Республике Хакассия; первоочередные поиски новых месторождений баритового сырья следует организовать близ имеющихся транспортных инфраструктур на Алчано-Бикинской и Муравьево-Амурской баритоносных площадях в Приморском крае, на Анюйской и Нижне-Амурской площадях в Хабаровском крае, на Сакмарской площади в Республике Бошкортостан. Предложено сохранить стабильный импортньй товарный поток барита от постоянных партнеров 8 Республике Казахстан в экономических условиях стран Таможенного союза, а также рассмотреть возможность формирования новых импортных потоков баритового сырья из Индии и Лаоса.
\end{abstract}

\section{Ключевые слова:}

Баритовое сырье, импортозависимость, критический товарный продукт, минерально-сырьевая база, проекты.

\section{Введение}

Барит, или «тяжелый шпат», представляет собой природный сульфат бария. Он используется преимущественно в качестве утяжелителя буровых растворов (более 75 \% потребления), инертного и слабоактивного наполнителя в лакокрасочной, резиновой, бумажной, стекольной, цементной, строительной промышленности, в производстве пластмасс, керамики (16-18\%) и в качестве химического сырья для производства соединений бария (6-7 \%) [1-4].

После распада СССР большая часть источников барита оказались за пределами России - в Казахстане и Грузии. Если в 1980-е гг. потребности нефтегазовой промышленности СССР составляли 550-725 тыс. т/год и на 80-90 \% удовлетворялись собственной добычей барита, то в 1990-е гг. в России доля его импорта превысила $50 \%$ [3-8].

Лидерами мировой добычи барита являются Китай, Индия и Марокко, главными экспортерами - Китай, Индия, Марокко, Турция и Казахстан, ведущими импортерами - США, Саудовская Аравия, Канада, Кувейт, Норвегия, Германия и Италия. В США, несмотря на значительную собственную добычу барита (400-700 тыс. т/год), ввиду импорта до 87 \% его потребления этот товарный продукт относятся к крити- ческим материалам [9]. Такая же ситуация имеет место с баритовым сырьем и в Европейском Союзе, импортирующим до 82 \% от его потребления [10]. В Китае, несмотря на его лидерство в добыче, барит также является критическим товарным продуктом $[11,12]$.

Наличие импортной зависимости по сырью для нужд российской нефтегазовой отрасли требует анализа географии национальной минерально-сырьевой базы барита и предприятий, добывающих и потребляющих баритовое сырье, тенденций спроса и предложения барита на российском и мировом рынках, а также выработки предложений по решению проблемы импортозависимости.

\section{Методы исследования}

С целью изучения российской отрасли производства и потребления барита были обработаны данные по движению их товарных потоков за 1996-2020 гг., по динамике мировых цен и цен российского импорта и экспорта баритового сырья. Источники информации: Государственные доклады Федерального агентства недропользования Российской Федерации [13], базы данных Федеральной службы государственной статистики [14] и Федеральной таможенной службы [15] России, статистические данные ООН [16], обзоры информационных центров $[17,18]$. 
Объемы товарных потоков барита учтены в метрических тоннах, а цены - в долларах США за тонну. Доли импорта определялись по отношению импортных объемов к объемам национального потребления и реализации (потребление+экспорт), доли экспорта по отношению экспортных объемов к объемам национального производства. Среднемировые цены барита рассчитаны по суммарным объемам и стоимости мирового экспорта и импорта. Запасы и ресурсы барита пересчитана на $100 \% \mathrm{BaSO}_{4}$. Темпы годовых изменений во времени абсолютных показателей (объемы, стоимость) определяются в виде сложных процентов, относительных показателей (цены, доли) - в виде простых процентов. Имеются лакуны данных по отдельным периодам, не позволяющие рассчитывать производные величины (цены, доли) - они исключались из вычислений и построений графиков. При различии смежных данных (например, трансграничных продаж по данным экспортеров и импортеров) из них выбиралась наименьшая величина.

\section{Анализ баритовой отрасли России и мира}

Российское потребление барита в 2020 г. составило 299 тыс. т, или 3,4 \% от его мирового производства/потребления (8,2 млн т). В международной торговле находится 55-60 \% добытого барита. Национальная добыча баритового сырья в России составила в 2020 г. 244 тыс. т. Импортный поток баритового сырья в Россию достигает 64 тыс. т (2020 г.) - на грани порога импортозависимости (25\%).

\section{Состояние баритовой отрасли в России}

На территории России добычу барита в настоящее время осуществляют АО «Барит» и ООО «Боградский ГОК» на Толчеинском баритовом месторождении в Республике Хакасия (рис. 1). В 2004 г. была прекращена добыча на Хойлинском баритовом месторождении в Республике Коми (АО «Хойлинский ГОК»), а в 2012 г. прекратил работу АО «Салаирский химический комбинат», разрабатывавший сульфидно-баритовое месторождение Кварцитовая Сопка в Кемеровской области.

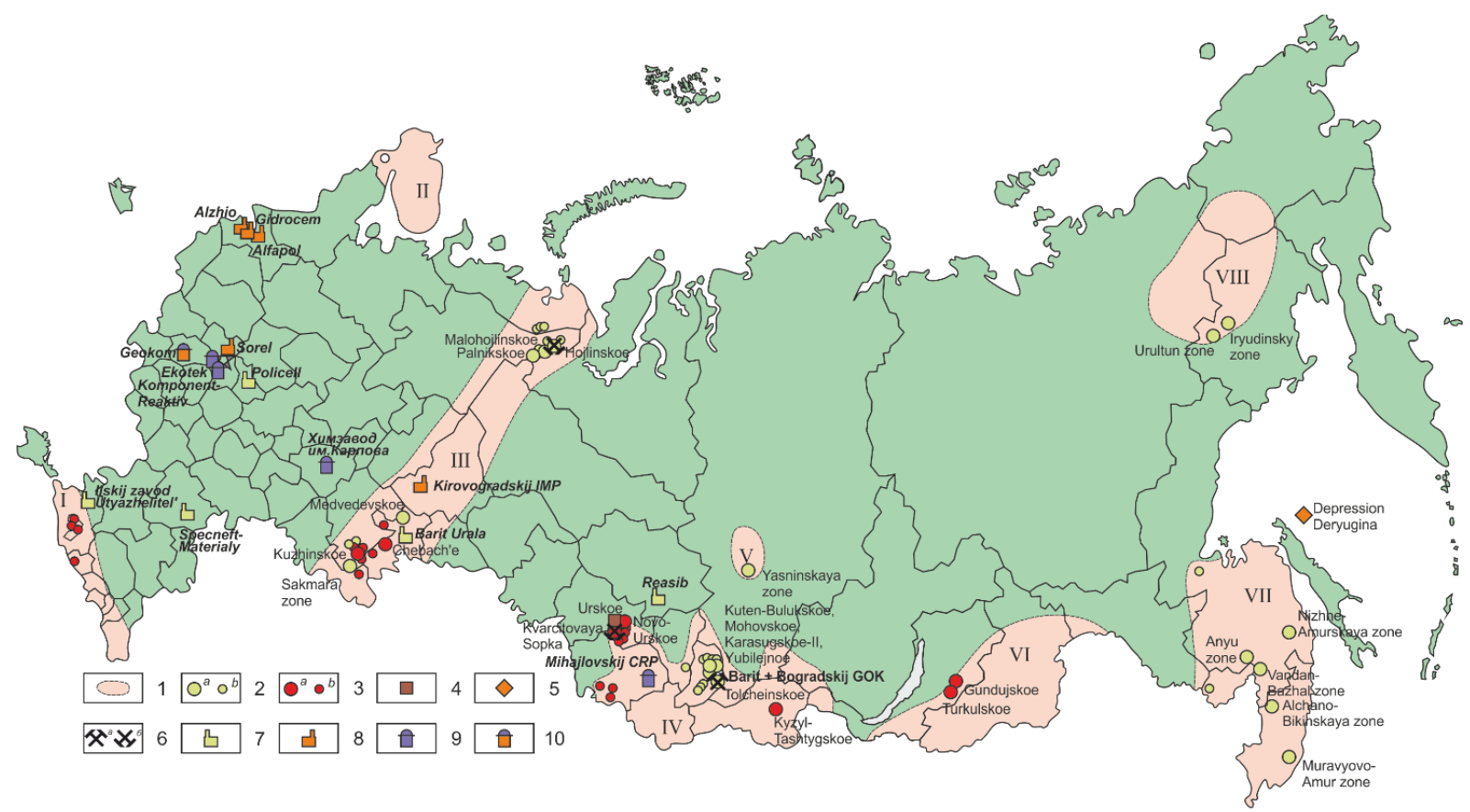

Рис. 1. Баритоносные провинции, месторождения и проявления барита, предприятия, добывающие и перерабатывающче баритовый продукт: 1 - баритоносные провинции (I-Северо-Кавказская, II - Кольская, III - Уральская, IV - Алтае-Саянская, V-Енисейская, VI - Забайкальская, VII - Сихотэ-Алинская, VIII - Колымская); 2, 3 - баритовые месторождения и проявления (a - с запасами свыше 500 mыс. $\mathrm{m} \mathrm{BaSO}_{4}$ и/или ресурсами свыше 1 млн $\mathrm{m} \mathrm{BaSO}_{4}, 6$-малье месторождения и проявления с небольшими запасами/ресурсами): 2 - собственно баритовые месторождения, 3 - комплексные сульфидно-баритовые месторождения; 4 - техногенные баритовые месторождения; 5 - глубоководные площади распространения баритовых конкреций; 6 - горнодобывающие предприятия, реализующие баритовый конщентрат ( $а$ - действующче, б - остановленные), 7-10 - предприятия по производству: 7 - баритовых буровых смесей, 8 - рентгенозащитных строительных смесей, 9 - бариевых химикатов, 10 - тонкодисперсных баритовых порошков - наполнителей красок

Fig. 1. Barite-bearing provinces, deposits and manifestations of barite, enterprises producing and processing barite products: 1 - barite-bearing provinces (I - North Caucasus, II - Kola, III - Ural, IV - Altai-Sayan, V - Yenisei, VI Trans-Baikal, VII - Sikhote-Alin, VIII - Kolyma); 2, 3 - barite deposits and manifestations (a - with reserves of more than 500 thousand tons of $\mathrm{BaSO}_{4}$ and/or resources of more than 1 million tons of $\mathrm{BaSO}_{4}, b-$ small deposits and manifestations with small reserves/resources): 2 - barite deposits proper, 3 - complex sulfide-barite deposits; 4 - technogenic barite deposits; 5 -deep-water areas of distribution of barite nodules; 6 - mining enterprises that sell barite concentrate ( $a$ - active, $b$-closed), 7-10 - enterprises that produce: 7 - barite drilling mixes, 8 -X-ray protective construction mixes, 9 - barium chemicals, 10 - fine barite powders-paint fillers 
Динамика рынка барита в России за период 19962020 гг. - на рис. 2. Если в 1996-2007 гг. добыча барита составляла $50-90$ тыс. т/год, то с 2008 г. начался ее рост до 434 тыс. т в 2016 г. Среднегодовые изменения объемов добычи барита в России за 1996-2016 гг. составляют $+12,8 \% /$ год. В дальнейшем наблюдается спад добычи барита вплоть до 184 тыс. т в 2018 г. Серьезные риски обеспечения поставок баритового сырья на российский рынок проявляются по факту единственного источника - добычи на Толчеинском месторождении с ограниченными остаточными запасами барита (1,2 млн т). При годовой национальной потребности барита в 300-400 тыс. т/год этих запасов хватит лишь на 3-4 года.

Потребление барита за 1996-2016 гг. непрерывно возрастает (с 32 до 420 тыс. т/год), опережая рост объемов национальной добычи баритового сырья. Среднегодовой рост объемов добычи барита в России за 1996-2016 гг. составляет +16,1 \%. Позднее потребление баритового сырья ввиду падения цен на нефть и газ, сопровождавшегося сокращением объемов нефтегазового бурения, упало к 2018 г. до нового минимума в 208 тыс. т, а затем вернулось к росту до 299 тыс. т в 2020 г.

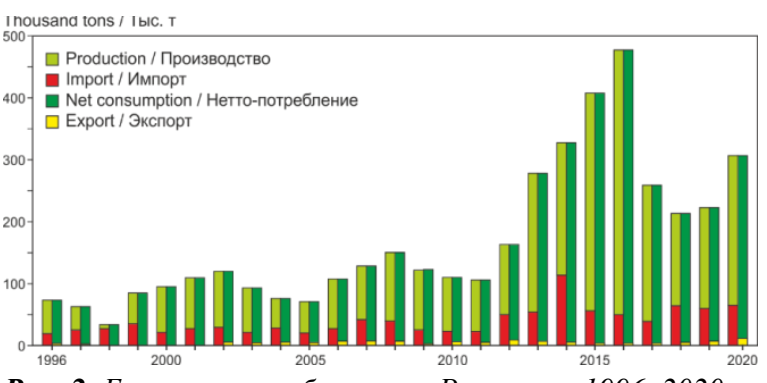

Pис. 2. Баланс рынка барита в России за 1996-2020 г2. Составлено по обобщенным данным [13-18]

Fig. 2. Barite market balance in Russia for 1996-2020. Compiled from generalized data [13-18]

Предприятия, потребляющие барит:

- производители утяжелителей буровых растворов АО «Ильский завод Утяжелитель - НПО «Бурение» (пос. Ильский Северского района Краснодарского края), ООО «Барит Урала» (г. Челябинск), АО «Спецнефтематериалы» (г. Волгоград), АО «НПО «Полицелл» (г. Владимир), ООО «НПО «Реасиб» (г. Томск);

- производители рентгенозащитных строительных смесей: ООО «Альфапол», ООО «Ажио» и ООО «Гидроцем» в г. Санкт-Петербург, ООО «Сорель» (г. Москва), ООО «Кировградский завод промышленных смесей» (г. Кировоград Свердловской области);

- производители баритовых химикатов: ООО «Экотек - Завод химических компонентов» и ООО «Компонент-Реактив» в г. Москва, АО «Химический завод им. Л.Я. Карпова» (г. Менделеевск, Республика Татарстан) ООО «Михайловский завод химических реактивов» (г. Барнаул);

- производители баритовых наполнителей красок АО «Геоком» (пос. Полотняный Дзержинского района Калужской области).
Перекрытие дефицита потребления компенсируется по импорту. В 1996-2006 гг. импорт барита находился в интервале 20-35 тыс. т/год (рис. 3), но начиная с 2007 г. импортные поставки увеличились до 30-55 тыс. т/год в 2007-2012 гг. и до 40-65 тыс. т/год в 2013-2020 гг. Среднегодовые изменения объемов импорта барита в России за 1996-2020 гг. составляет $+4,2 \% /$ год.

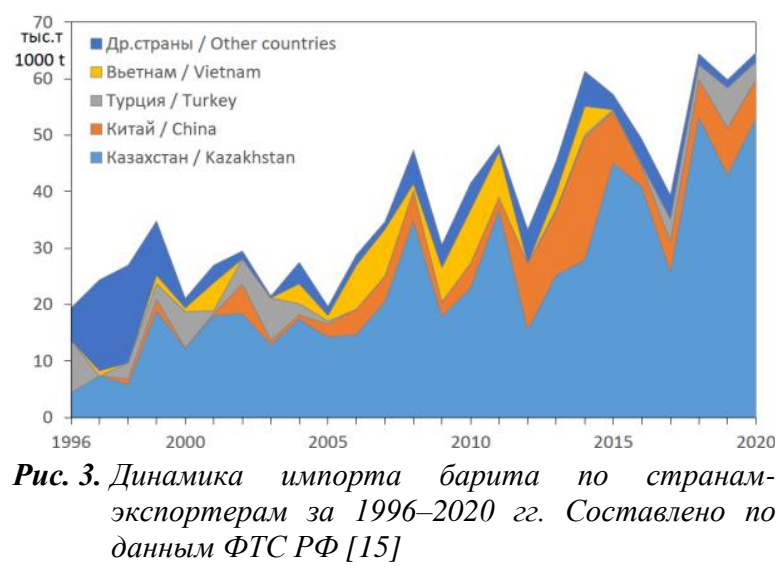

Fig. 3. Dynamics of barite imports by exporting countries for 1996-2020. Compiled according to the Federal Customs Service of the Russian Federation [15]

Основные поставщики барита в Россию - добывающие предприятия Казахстана (АО «Восточное рудоуправление» на Чиганакском месторождении, АО «Жайремский ГОК» на Жайремском месторождении и TOO «Global Chemicals Company» на месторождении Бестобе), осуществляют непрерывно растущие поставки - вплоть до 53 тыс. т в 2018 г. (в 1990-е гг. 22-30 \% российского импорта, в 10-е годы - 55-83\%). Второй по значимости источник барита - Китай, поставляющий в Россию до 22 тыс. т/год. В 2000-2013 гг. осуществлялись поставки баритового сырья из Вьетнама (до 10 тыс. т/год), но в этой стране имеется рост собственного потребления и его отгрузки прекратились. Наоборот в 2017 г. возобновился импорт барита из Турции (до 7 тыс. т/год) после перерыва с 2007 г.

Динамика мировых цен на барит (рис. 4) включает следующие события: стабильный уровень цен экспорта 50-60 \$США/т до 2005 гг.; их рост начиная с 2006 г. до в 2000-2012 гг. до 145-150 \$США/т в 2013-2016 гг. и снижение до 135-145 \$США/т в 2017-2020 гг. Среднемировые цены импорта (SIF) барита выше среднемировых цен экспорта (FOB) на $15-40 \%$. Российские цены импорта барита на 25-50 \% выше среднемировых цен импорта, но в 2013-2014 гг. были ниже мировых на $-4 \ldots-11 \%$. В то же время российские цены импорта барита из Казахстана (SIF) лишь на 10-12 \% выше цен экспорта Казахстана (FOB), что обусловлено короткой транспортной логистикой поставок.

По динамике долей импорта барита (рис. 5) этот продукт включительно по 1999 г. был импортозависимым (до $84 \%$ от потребления), но начиная с 2000 г. (после наращивания национальной добычи) сложилась ситуация, что доля его импорта колеблется на 
грани порога импортозависимости (25\%) - от $7 \%$ (2004 г.) до $35 \%$ (2014 г.).

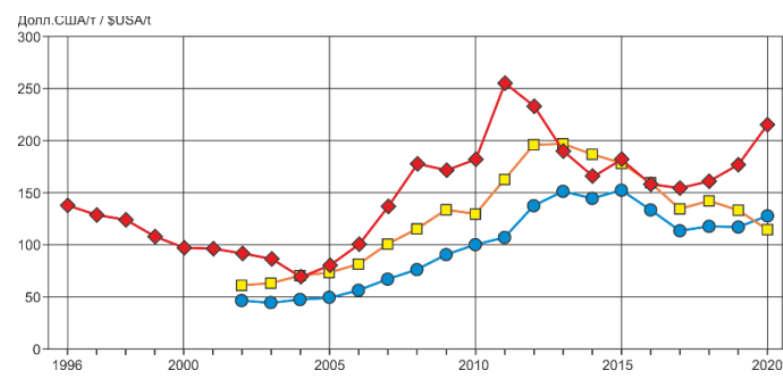

Pис. 4. Динамика иен на барит за 1996-2020 ге. Составлено по данным [15-18]. О- среднемировой экспорт; - - среднемировой импорт; $\diamond-и м$ порт в Россию

Fig. 4. Dynamics of barite prices for 1996-2020. Compiled according to [15-18]. O - global average export; $\square$ - global average import; $\diamond$-import to Russia

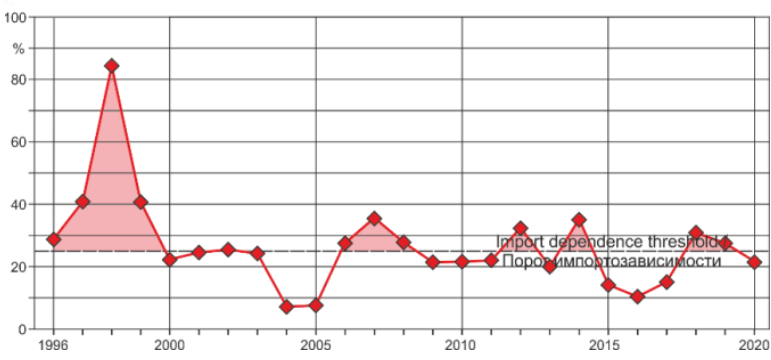

Рис. 5. Динамика долей импорта (от потребления) барита в Россию за 1996-2020 г2.

Fig. 5. Dynamics of the share of imports (from consumption) of barite to Russia for 1996-2020

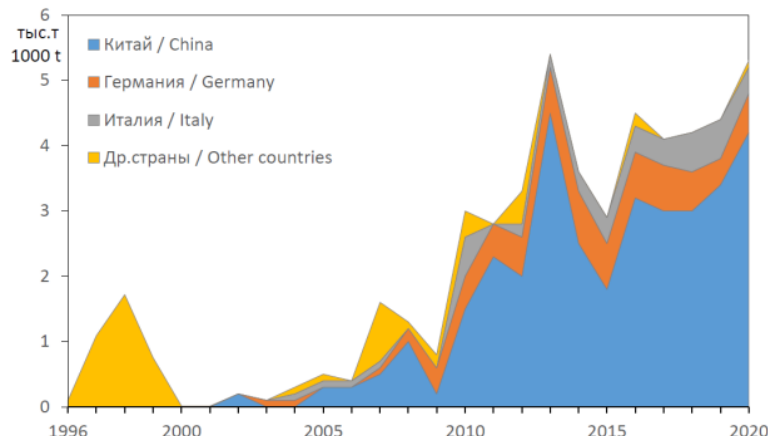

Puc. 6. Динамика импорта сульфата бария (синтетического барита) по странам-экспортерам за 1996-2020 г2. Составлено по данным ФТС РФ [15]

Fig. 6. Dynamics of imports of barium sulfate (synthetic barite) by exporting countries for 1996-2020. Compiled according to the Federal Customs Service of the Russian Federation [15]

Кроме природного барита импортируется также синтетический сульфат бария, причем начиная с 2004 г. наблюдается увеличение импортного потока последнего, вплоть до 5,5 тыс. т в 2013 г. (рис. 6). Синтетический сульфат бария используется в производстве рентгенозащитных строительных смесей и катодной массы свинцовых аккумуляторов. Отмечаются и провалы спроса синтетического барита в кризисные 2009 и 2014-2015 гг. Главный экспортер за весь период анализа - Китай. Цены российского импорта синтетического сульфата бария в последние годы составляли 680-790 \$США/т при среднемировых ценах его экспорта 390-420 \$США/т.

\section{Состояние минерально-сырьевой базы барита в России}

Месторождения барита можно разделить на четыре основных типа: стратиформные осадочные; стратиформные вулканогенно-осадочные; метасоматические и остаточные. Геологических формаций баритовых месторождений можно выделить значительно больше [19], но все они укладываются в вышеперечисленные четыре группы. По технологическому признаку выделяют мономинеральные баритовые и комплексные (сульфидно-баритовые) месторождения.

Запасы барита в России по категориям $\mathrm{A}+\mathrm{B}+\mathrm{C}_{1}+\mathrm{C}_{2}$ составляют 19,8 млн т $\mathrm{BaSO}_{4}$, прогнозные ресурсы по категориям $\mathrm{P}_{1}+\mathrm{P}_{2}-115$ млн т $\mathrm{BaSO}_{4}$ [4].

В разработке в настоящее время находится только одно Толчеинское мономинеральное баритовое месторождение в Республике Хакассия с остаточными запасами на 01.01.2020 г. 1,2 млн т $\mathrm{BaSO}_{4}$, что достаточно лишь на 5 лет при текущем уровне добычи.

В июне 2020 г. состоялось начало работы КызылТаштыгского ГОКа на одноименном баритполиметаллическом месторождении в Республике Тыва с запасами барита 0,868 млн т $\mathrm{BaSO}_{4}$ по категории $\mathrm{C}_{2}$ [20], однако технологической схемой предполагается извлечение лишь медных, цинковых и свинцовых концентратов. Отказ в выпуске попутного баритового концентрата в этом проекте обоснован его низким качеством и нерентабельностью его модификации до приемлемых кондиций.

До 2014 г. в Кемеровской области барит выпускался Салаирским ГОКом при разработке баритполиметаллического месторождения Кварцитовая Сопка (запасы по кат. $\mathrm{B}+\mathrm{C}_{1}+\mathrm{C}_{2} 5,304$ млн т $\mathrm{BaSO}_{4}$ ). В июне 2014 г. работы ГОКа были остановлены по решению его владельцев (ООО «УГМК-Холдинг») на основании нерентабельности производства. Выпускаемый Салаирским ГОКом баритовый концентрат (до 40 тыс. т/год) также был невысокого качества, кроме этого, были проблемы с реализацией золотосодержащего свинцового концентрата, переработка которого в России отсутствовала, и основная причина прекращения работы ГОКа - устаревшее и изношенное горное и обогатительное оборудование не обновлялось. В этом районе известны и другие месторождения барит-сульфидных руд: Ново-Урское (запасы по кат. $\mathrm{C}_{2}$ 1,9 млн т $\left.\mathrm{BaSO}_{4}\right)$, Белоключевское $(0,4$ млн т), Первый Рудник (0,4 млн т), Первомайское $(0,3$ млн т) и Самойловское (0,11 млн т).

Предлагается проект совместного освоения Гундуйского $\left(4,147\right.$ млн $\left.\mathrm{T} \quad \mathrm{BaSO}_{4}\right)$ и Туркульского (1,552 млн т $\mathrm{BaSO}_{4}$ ) медно-баритовых месторождений в Республике Бурятия с годовым выпуском 70 тыс. т баритового концентрата [21]. Здесь также возможна проблема качества баритовой продукции.

Многочисленные мелкие барит-сульфидные месторождения в Челябинской (Чебачье, Талганское, 
Молодежное) и Мурманской (Салланлатва) областях, Алтайском крае (Заречное, Юбилейное, Среднее) и Республике Адыгея (Белореченское) пока не представляют интереса ввиду сложности обогащения их руд и необходимости значительных капитальных затрат на их освоение.

С позиции получения качественного баритового продукта предпочтительно освоение мономинеральных баритовых месторождений.

По запасам баритового сырья в России наиболее значима Хойлинская группа монобаритовых месторождений в Республике Коми. В трех месторождениях (Хойлинское, Малохойлинское и Пальникское) учтены запасы $\mathrm{BaSO}_{4}$ по кат. $\mathrm{B}+\mathrm{C}_{1}+\mathrm{C}_{2} 1,79,3,58$ и 4,59 млн т, соответственно, а также прогнозные ресурсы Уральско-Пайхойской баритоносной площади по кат. $\mathrm{P}_{1}+\mathrm{P}_{2}-16,1$ млн т $[4,22]$. В 1998 г. была осуществлена попытка освоения Хойлинского месторождения АО «Хойлинский ГОК», но далее пробного выпуска малых партий кускового (недробленного) барита дело не пошло, и в 2004 г. проект был остановлен ввиду высоких эксплуатационных расходов (в условиях Крайнего Севера) и низкой стоимости выпускаемой продукции.

Остаточные месторождения выветривания над барит-сульфидными месторождениями также являются монобаритовыми, к тому же они расположены на дневной поверхности и сложены рыхлыми рудами, что будет способствовать снижению эксплуатационных затрат при их разработке. Однако запасы таких месторождений небольшие. Наибольший интерес представляет месторождение Медведевское $\left(0,631\right.$ млн т $\left.\mathrm{BaSO}_{4}\right)$ в Челябинской области [23], и есть перспективы обнаружения таких месторождений в Республике Башкортостан [24].

Большой интерес представляют баритовые месторождения и проявления, изучение которых остановлено на поисковой стадии, а также перспективные баритоносные площади.

Наиболее значима группа месторождений и проявлений в Республике Хакассия, расположенная к северу от разрабатываемого Толчинского баритового месторождения: Кутень-Булукское (прогнозные ресурсы 3,6 млн т $\mathrm{BaSO}_{4}$ ), Моховское (2,5 млн т), Карасугское-ІІ (1,9 млн т), Юбилейное (1,0 млн т), а также другие проявления (1,6 млн т) [4, 25]. Их оценка и разведка может послужить основой для возобновления истощаемой ресурсной базы добывающих компаний АО «Барит» и ООО «Боградский ГОК».

Из перспективных баритоносных площадей следует отметить в первую очередь участки недр близ имеющихся транспортных инфраструктур (рис. 1): Сакмарская (прогнозные ресурсы 4,6 млн т $\mathrm{BaSO}_{4}$ ) в Республике Бошкортостан, Алчано-Бикинская (10,0 млн т) и Муравьево-Амурская (3,6 млн т) в Приморском крае, Анюйская (8,1 млн т) и Нижне-Амурская (3,0 млн т) в Хабаровском крае $[4,26]$. Удаленные Урультунская и Ирюдинская баритоносные площади в Магаданской области, несмотря на значительные прогнозные ресурсы (33,7 и 4,0 млн т $\mathrm{BaSO}_{4}$, соответственно), не проглядываются на предмет их освоения. Аналогично, проблемна Ясинская баритоносная площадь (ресурсы 4,6 млн т $\mathrm{BaSO}_{4}$ ) в Красноярском крае, расположенная за крупными водными преградами Енисея и Ангары.

Отдельно следует отметить возможность освоения техногенных месторождений барита, образованных на обогатительных фабриках, извлекавших только сульфидные концентраты $[27,28]$. В пос. Урск Гурьевского района Кемеровской области (рис. 1) находится Урское хвостохранилище отходов обогащения руд Ново-Урского барит-полиметаллического месторождения, которое представляет собой мелко измельченную барит-гематит-кварцевую смесь, содержащую до 50 \% барита. Ресурсы барита этого хвостохранилища превышаю 1,5 млн т в пересчете на $\mathrm{BaSO}_{4}$. Учитывая компактное нахождение хвостов на дневной поверхности, дробленое и измельченное состояние баритсодержащего хвостового материала, исключаются эксплуатационные расходы по добыче и дроблению рудной массы, а затраты на доведение баритовых концентратов до требуемой кондиции будут минимальными. Выход баритового концентрата с этого объекта может составить до 100 тыс. т в год.

Принципиально новым источником баритового сырья могут стать глубоководные хемогенные осадки барита, обнаруженные во впадине Дерюгина в Охотском море (рис. 1) [29]. Они обнаружены на площади до 16 кв. км на глубине залегания 1470-1480 м в виде травертиноподобных скоплений и корок. Ресурсы баритовых осадков составляют до 10 млн т $\mathrm{BaSO}_{4}$, что отвечает средней концентрации баритовых образований до $600 \mathrm{\kappa г} / \mathrm{m}^{2}[30,31]$. Учитывая, что проекты освоения месторождений глубоководных железомарганцевых конкреций $[32,33]$ имеют пороговую рентабельность при концентрации марганцевых образований свыше 5 кг/ $\mathrm{m}^{2}$, при цене баритовой продукции, сопоставимой с ценами на марганцевый концентрат, будут окупаемыми и проекты разработки глубоководных баритовых осадков. Вопрос лишь в развитии техники и технологии глубоководной добычи твердых полезных ископаемых.

\section{Обзор мирового рынка баритового сырья}

Баритовые месторождения в геологическом плане достаточно широко распространены и в плане размещения добывающих и потребляющих производств первоначально осваивались наиболее близкие объекты на собственной национальной территории. В первой половине XX в. и добывающие, и перерабатывающие барит производства располагались непосредственно в Германии, Англии, Италии, Франции и США, импортно-экспортные поставки не превышали 20 \% от потребления. Использование барита шло в основном на производство лакокрасочного наполнителя (свыше 50 \% потребления) и бариевых химикатов.

Если в 1950 г. мировое производство и потребление барита составляло 1,3 млн т, то уже в 1960 г. выросло до 2,8 млн т, а к 2020 - 8,2 млн т (таблица).

Но со временем национальные ресурсы барита сокращались и происходила трансформация товарных потоков от производителей к потребителям. 
Таблица. Лидеры мирового производства, экспорта, импорта и потребления баритового сырья

Table. Leaders in the global production, export, import and consumption of barite raw materials

\begin{tabular}{|c|c|c|c|c|c|c|c|c|}
\hline № & Страны/Countries & Год/Year & № & Страны/Countries & Год/Year & № & Страны/Countries & Год/Year \\
\hline & & 1960 & & & 1990 & & & 2020 \\
\hline \multicolumn{9}{|c|}{ Производство, тыс. т/Production, thousand tons } \\
\hline 1 & США/USA & 700 & 1 & Китай/China & 1462 & 1 & Китай/China & 2500 \\
\hline 2 & Германия/Germany & 498 & 2 & Индия/India & 633 & 2 & Индия/India & 2000 \\
\hline 3 & Мексика/Мехісо & 271 & 3 & CCCP/USSR & 500 & 3 & Марокко/Morocco & 800 \\
\hline 4 & Италия/Italy & 143 & 4 & США/USA & 430 & 4 & Казахстан/Kazakhstan & 600 \\
\hline 5 & Канада/Canada & 140 & 5 & Турция/Turkey & 367 & 5 & Лaоc/Laos & 400 \\
\hline 6 & CCCP/USSR & 127 & 6 & Марокко/Morocco & 364 & 6 & США/USA & 400 \\
\hline 7 & Пеpy/Peru & 110 & 7 & Мексика/Мехісо & 306 & 7 & Мексика/Мехісо & 280 \\
\hline 8 & Франция/France & 106 & 8 & Германия/Germany & 233 & 8 & Россия/Russia & 244 \\
\hline 9 & Югославия/Yugoslavia & 103 & 9 & Болгария/Bulgaria & 193 & 9 & Иран/Iran & 200 \\
\hline 10 & Греция/Greece & 102 & 10 & Таиланд/Thailand & 139 & 10 & Турция/Turkey & 200 \\
\hline & Мир, всего/World, total & 2809 & & Мир, всего/ World, total & 5654 & & Мир, всего/World, total & 8288 \\
\hline \multicolumn{9}{|c|}{ Экспорт, тыс. т/Export, thousand tons } \\
\hline 1 & Мексика/Мехісо & 159 & 1 & Китай/China & 1443 & 1 & Индия/India & 1460 \\
\hline 2 & Германия/Germany & 136 & 2 & Марокко/Morocco & 374 & 2 & Марокко/Morocco & 1074 \\
\hline 3 & Канада/Canada & 122 & 3 & Индия/India & 304 & 3 & Китай/China & 543 \\
\hline 4 & Греция/Greece & 110 & 4 & Турция/Turkey & 177 & 4 & Казахстан/Kazakhstan & 217 \\
\hline 5 & Пepy/Peru & 104 & 5 & Болгария/Bulgaria & 160 & 5 & Турция/Turkey & 181 \\
\hline 6 & Югославия/Yugoslavia & 103 & 6 & Таиланд/Thailand & 105 & 6 & Иран/Iran & 162 \\
\hline 7 & Марокко/Morocco & 56 & 7 & Ирландия/Irish & 101 & 7 & Нидерланды/Netherlands & 129 \\
\hline 8 & Бразилия/Brazil & 48 & 8 & Франция/France & 78 & 8 & Таиланд/Thailand & 103 \\
\hline 9 & Италия/Italy & 34 & 9 & Нидерланды/Netherlands & 73 & 9 & Мексика/Мехісо & 101 \\
\hline 10 & Испания/Spain & 25 & 10 & Бельгия/Belgium & 52 & 10 & Пакистан/Pakistan & 92 \\
\hline & Мир, всего/World, total & 973 & & Мир, всего/ World, total & 3126 & & Мир, всего/World, total & 4442 \\
\hline № & Страны/Countries & $\begin{array}{l}\text { Год } \\
\text { Year }\end{array}$ & № & Страны/Countries & $\begin{array}{l}\text { Год } \\
\text { Year }\end{array}$ & № & Страны/Countries & $\begin{array}{l}\text { Год } \\
\text { Year }\end{array}$ \\
\hline & & 1960 & & & 1990 & & & 2020 \\
\hline \multicolumn{9}{|c|}{ Импорт, тыс. т/Import, thousand tons } \\
\hline 1 & США/USA & 582 & 1 & США/USA & 988 & 1 & США/USA & 1046 \\
\hline 2 & CCCP/USSR & 60 & 2 & Германия/Germany & 232 & 2 & Сауд. Аравия/Saudi Arabia & 633 \\
\hline 3 & Франция/France & 56 & 3 & Англия/England & 217 & 3 & Кувейт/Kuwait & 208 \\
\hline 4 & Англия/England & 46 & 4 & Норвегия/Norway & 194 & 4 & Канада/Canada & 160 \\
\hline 5 & Нидерланды/Netherlands & 37 & 5 & CCCP/USSR & 123 & 5 & Нидерланды/Netherlands & 133 \\
\hline 6 & Бельгия/Belgium & 35 & 6 & Япония/Japan & 116 & 6 & Таиланд/Thailand & 128 \\
\hline 7 & $\begin{array}{l}\text { Тринидад и Табаго } \\
\text { Trinidad \& Tobago }\end{array}$ & 28 & 7 & Нидерланды/ Netherlands & 95 & 7 & Норвегия/Norway & 118 \\
\hline 8 & Япония/Japan & 18 & 8 & Индонезия/Indonesia & 82 & 8 & Италия/Italy & 96 \\
\hline 9 & Венесуэла /Venezuela & 18 & 9 & Венесуэла /Venezuela & 81 & 9 & Оман/Oman & 93 \\
\hline 10 & Германия/Germany & 15 & 10 & Италия/Italy & 74 & 10 & Германия/Germany & 91 \\
\hline & Мир, всего/World, total & 950 & & Мир, всего/World, total & 2575 & & Мир, всего/World, total & 3558 \\
\hline \multicolumn{9}{|c|}{ Потребление, тыс. т/Consumption, thousand tons } \\
\hline 1 & США/USA & 1080 & 1 & США/USA & 1434 & 1 & Китай/China & 2046 \\
\hline 2 & Германия/Germany & 377 & 2 & CCCP/USSR & 623 & 2 & США/USA & 1707 \\
\hline 3 & CCCP/USSR & 188 & 3 & Германия/Germany & 428 & 3 & Сауд. Аравия/Saudi Arabia & 628 \\
\hline 4 & Мексика/Mexico & 113 & 4 & Индия/India & 329 & 4 & Индия/India & 551 \\
\hline 5 & Италия/Italy & 110 & 5 & Мексика/Мехісо & 301 & 5 & Россия/Russia & 289 \\
\hline 6 & Англия/England & 103 & 6 & Англия/England & 260 & 6 & Канада/Canada & 282 \\
\hline 7 & Алжир/Algeria & 65 & 7 & Турция/Turkey & 190 & 7 & Кувейт/Kuwait & 207 \\
\hline 8 & Китай/China & 61 & 8 & Норвегия/Norway & 178 & 8 & Мексика/Мехісо & 179 \\
\hline 9 & Япония/Japan & 41 & 9 & Япония/Japan & 134 & 9 & Германия/Germany & 131 \\
\hline 10 & Нидерланды/Netherlands & 37 & 10 & Италия/Italy & 109 & 10 & Норвегия/Norway & 115 \\
\hline & Мир, всего/World, total & 2809 & & Мир, всего /World, total & 5654 & & Мир, всего/World, total & 8288 \\
\hline
\end{tabular}

В конце 1950-х гг. началось резкое увеличение потребления барита в качестве утяжелителя буровых растворов, что привело к увеличению его добычи в крупных нефтегазодобывающих странах (США, СССР, Мексика, Канада), появлению новых экспортных потоков (из Марокко, Мексики, Канады и других стран), импортных потоков в другие добывающие страны (Алжир, Венесуэла, Тринидад/Табаго), а также формирование транзитных потоков баритового сырья через Нидерланды, Бельгию и Сингапур.
Безусловный лидер потребления барита - США (максимум 3,2 млн т в 2008 г.), несмотря на наращивание его добычи (до 2,6 млн т в 1981 г.), в 1985 г. стали нетто-импортером баритового сырья, к 2019 г. доведя долю импорта до 87 \% от потребления.

Германия - в 1960 г. второй по значимости потребитель барита - снизила уровень добычи и, несмотря на сокращение потребления, в 1979 г. стала нетто-импортером, ввезя в 2020 г. $70 \%$ от его потребления. 
СССР наращивал потребление баритового сырья вплоть до максимума в 0,85 млн т в 1978 г., но после 1991 г. произошло разделение товарных потоков новых стран СНГ, и Россия, Азербайджан и Туркменистан стали импортозависимыми по сырью, а Казахстан - экспортером барита.

Китай, добывший в 1955 г. всего 25 тыс. т баритового сырья, интенсифицировал в 1980-е гг. работы по развитию баритодобывающей отрасли и наращивает объемы его добычи вплоть до максимума в 5,0 млн т в 2008 г. Параллельно росли объемы экспорта барита с максимумом в 2008 г. (3,8 млн т) и его национального потребления (преимущественно лакокрасочного наполнителя), составившего в 2020 г. 2,0 млн т. С 1980 по 2017 гг. Китай был мировым лидером международной торговли баритом.

Индия также начала интенсифицировать добычу баритового сырья в 1975 г., доведя ее до максимума в 2,3 млн т в 2010 г. Большая часть добытого барита идет на экспорт, и начиная с 2018 г. Индия стала мировым лидером международной торговли баритового сырья. Национальное потребление барита в Индии находится на уровне $0,5-0,6$ млн т/год.

Марокко, начав в 1958 г. разработку баритовых месторождений, полностью ориентировало экспортное направление этого сырья. Длительное время (1980-2005 гг.) уровень добычи и экспорта барита составлял 0,4-0,5 млн т/год, в дальнейшем он увеличился до 0,7-1,2 млн т/год, и Марокко традиционно занимает третье место в международной торговле баритовым сырьем.

Мексика, имея собственное значимое потребление барита (до 0,5 млн т в 2004 г.), всегда была его неттоэкспортером (0,2-0,4 млн т/год), но в 1997 г. практически прекратила экспорт баритового сырья для обеспечения собственных потребностей и только в 2011 г. возобновила экспортные поставки.

Туриия, располагаясь вблизи европейских потребителей, с 1973 г. по настоящее время добывала и поставляла на экспорт 100-300 тыс. т/год, оставляя для собственного потребления 50-100 тыс. т/год.

Многие страны-экспортеры баритового сырья ввиду истощения собственных месторождений практически ушли с этого рынка международной торговли: Югославия в 1966 г., Германия в 1973 г., Греция в 1976 г., Перу в 1984 г., Таиланд в 1991 г., Ирландия в 1995 г. и Болгария в 2009 г.

Канада, длительное время экспортировавшая большую часть добытого баритового сырья (200-300 тыс. т/год), в 1972 г. резко сократила его внешние поставки, а с 2000 г. стала и нетто-импортером барита для нужд собственной нефтегазовой отрасли.

Появились новые добывающие баритовое сырье страны: Казахстан (до 600 тыс. т/год), Иран (до 450 тыс. т/год) и Лаос (до 400 тыс. т/год).

Норвегия, начавшая осваивать нефтегазовые месторождения Северного моря, с 1979 г. импортирует значительные объемы баритового сырья (100-300 тыс. т/год).

В последние годы ввиду истощения длительно разрабатываемых нефтяных месторождений значительно возросли объемы эксплуатационного бурения и произошло увеличение потребления баритового утяжелителя (и соответственно - импорта) не только в США, Канаде, России, но и в Саудовской Аравии (до 1,2 млн т/год), Казахстане (до 390 тыс. т/год), Кувейте (до 215 тыс. т/год), Аргентине (до 180 тыс. т/год), Индонезии (до 150 тыс. т/год) и ОАЭ (до 80 тыс. т/год).

Доля международной торговли баритовым сырьем от производства/потребления, составлявшая до 1980 г. 30-35 \%, в 1980-е гг. увеличилась до 50 \%, а в XXI в. до $55-60 \%$.

Сложилась ситуация, что основные лидеры баритового рынка имеют большой отрыв по объемам от других его участников: по добыче - Китай, Индия и Марокко, по экспорту - Индия, Китай и Марокко, по импорту США и Саудовская Аравия, по потреблению США, Китай и Саудовская Аравия.

Россия входит в десятку мировых лидеров по производству и потреблению баритового сырья. Объемы российского импортного товарного потока барита не велики по отношению к его мировой торговле $(0,8-1,2 \%)$. С одной стороны, дефицит сравнительно легко обеспечивается импортом (в нашем случае из Казахстана). С другой стороны, такие малые объемы импортного потока не способны влиять на цены и объемы главных торговых экспортно-импортных операций по баритовому сырью, формируемых взаимоотношениями крупных экспортеров (Индия, Китай и Марокко) и импортеров (США и Саудовская Аравия). Кроме этого, серьезным фактором для российского импорта является транспортная логистика, когда большинство потребителей баритового сырья находятся далеко от морских портов и транспортировка казахского барита становится предпочтительней и по ценам, и по срокам поставок. Доля казахского экспорта барита в Россию составляет 55-83 \%, доля российского импорта в экспорте баритового сырья Казахстана - 30-50 \%.

\section{Обсуждение результатов}

Учитывая, что объемы буровых работ при разведке и обустройстве нефтяных и газовых месторождений России будут оставаться на высоком уровне, проблема дефицита спроса на баритовое сырье остается актуальной. Она усугубляется тем, что в разработке находится всего одно месторождения барита, запасов которого достаточно лишь на 5-6 лет эксплуатации. Тем не менее есть все предпосылки ее решения путем интенсификации поисково-разведочных работ новых богатых месторождений барита и последующего вовлечения их в производство, а также за счет внедрения новых технологий обогащения баритового концентрата, снижающих его потери.

Снизить риски коллапса национальной добычи барита и купировать зависимость от импорта баритового сырья возможно в результате следующих действий:

- поиски и освоение новых баритовых месторождений с высококачественными рудами;

- внедрение новых технологий обогащения и переработки баритового сырья;

- сохранение стабильного импортного потока барита из Казахстана и организация новых импортных потоков баритового сырья. 
1. Поиски и освоение новых баритовых месторождений с высококачественными рудами. Вблизи действующего Толчеинского рудника в Хакасии имеется группа перспективных монобаритовых месторождений: Кутень-Булукское, Моховское, Карасугское-II и Юбилейное. Требуется осуществить оценку и разведку этих месторождений с последующим вовлечение в эксплуатацию.

Возможно возобновление разработки Хойлинской группы баритовых месторождений (Хойлинское, Малохойлинское и Пальникское) в Республике Коми. Со времени остановки Хойлинским ГОКом добычи барита в 2004 г. цены российского импорта баритового сырья увеличились с 85-100 до 140-150\$США/т к 2020 г., поэтому рентабельность этого проекта может быть выше.

Возможно обнаружение и новых месторождений барита, как в пределах известных Алтае-Саянской и Полярно-Уральской баритоносных провинций, так и на новых площадях, которые ранее в качестве перспективных на барит не рассматривались - Дальневосточной (в Хабаровском и Приморском краях), Уральской (Южный и Средний Урал), Забайкальской (Забайкальский край, Республика Бурятия), Енисейской (Красноярский край) и Колымской (Магаданская область, Республика Саха-Якутия). Первоочередные поисковые работы следует организовать близ имеющихся транспортных инфраструктур на АлчаноБикинской и Муравьево-Амурской баритоносных площадях в Приморском крае, на Анюйской и Нижне-Амурской площадях в Хабаровском крае, на Сакмарской площади в Республике Бошкортостан.

2. Внедрение новых технологий обогащения и переработки баритового сырья. Для всех освоенных комплексных месторождений барита серьезной проблемой является низкий показатель извлечения в концентрат $[34,35]$. Это результат нахождения барита в тесном срастании с другими минералами, в первую очередь с гематитом. Наиболее актуальной задачей обогащения является проблема раскрытия сростков зерен барита с примесями, которая может быть решена с использованием электроимпульсного дробления или ультразвуковой диспергации. Возможным решением может быть создание новых технических условий на коллективный барит-гематитовый концентрат, пригодный для производства утяжелителя буровых растворов, и также их новых композиций [36]. Экономически оправдан передел дешевых низкокачественных баритовых концентратов на более дорогой товарный сульфат бария путем его обработки серной кислотой или растворением их расплава с хлоридами натрия $[37,38]$. Возможно также создание технологической цепочки передела баритовых огарков (продуктов пирометаллургического передела сульфидных руд) с получением синтетического сульфата бария [39, 40].

3. Сохранение стабильного импортного потока барита из Казахстана и организация новых импортных потоков баритового сырья. В настоящее время главным зарубежным поставщиком барито- вого сырья является Казахстан, поставляя в Россию до 90 тыс. т/год. Одновременно он осуществляет экспортные поставки в Туркменистан (до 100 тыс. т/год), Азербайджан (до 55 тыс. т/год) и Узбекистан (до 40 тыс. т/год). В экономических условиях стран Таможенного союза организация стабильного товарного потока баритового сырья от постоянных партнеров в Республике Казахстан является малорисковой альтернативой политике импортозамещения.

Возможно возобновление импортных поставок барита из Вьетнама и формирование новых импортных потоков баритового сырья из Индии и Лаоса.

\section{Выводы}

1. Баритовое минеральное сырье в России является критическим товарным продуктом ввиду ограниченности его добычи на одном Толчеинском месторождении в Республике Хакассия и наличия значимых объемов импорта барита на границе порога импортозависимости.

2. В международной торговле баритовым сырьем по экспорту лидируют Индия, Китай и Марокко, а по импорту - США и Саудовская Аравия, причем доля мирового экспорта/импорта составляет 55-60 \% от мирового производства/потребления. Россия входит в десятку мировых лидеров по производству и потреблению. Малый размер российского импортного товарного потока барита $(0,8 \ldots 1,2 \%$ от международной торговли), с одной стороны, легко обеспечивается (в т. ч. и из второстепенных источников сырья), с другой стороны не способен влиять на цены и объёмы главных торговых экспортно-импортных потоков баритового сырья.

3. Сырьевая база баритового сырья в России проблемна ввиду нахождения наиболее перспективных месторождений и баритоносных площадей в удаленных районах Крайнего севера (в Магаданская область, Республика Коми, Ненецкий АО). Многие баритовые месторождения требуют геологического доизучения (оценки и разведки), аналогично необходимы поисковые работы на новых баритоносных площадях.

4. Решение проблемы критического состояния производства барита в России возможно путем возобновления добычных работ на Хойлинской группе баритовых месторождений (Хойлинское, Малохойлинское и Пальникское) в Республике Коми и на техногенном Урском месторождении в Кемеровской области. Необходимо произвести оценку и разведку известной группы баритовых месторождений (Кутень-Булукское, Моховское, Карасугское-ІІ и Юбилейное) к северу от выбывающего из эксплуатации Толчеинского месторождения в Республике Хакассия. Первоочередные поиски новых месторождений баритового сырья следует организовать близ имеющихся транспортных инфраструктур на Алчано-Бикинской и МуравьевоАмурской баритоносных площадях в Приморском крае, на Анюйской и Нижне-Амурской площадях 
в Хабаровском крае, на Сакмарской площади в Республике Бошкортостан.

5. Следует сохранить стабильный импортный товарный поток барита от постоянных партнеров в Рес-

\section{СПИСОК ЛИТЕРАТУРЫ}

1. Bearden S.D. Barite: World sources and the US market / Mining Engineering. - 1997. - V. 49. - № 11. - P. 87-88.

2. Ellis R. Barite - a vital ingredient // Mining Magazine. - 2004. V. 188. - № 5. - P. 38-39.

3. Петров И.М. Тенденции и особенности развития мирового и российского рынков обогащаемых видов неметаллического минерального сырья // Минеральные ресурсы России. Экономика и управление. -2010 . № 6. - С. 68-71.

4. Ахманов Г.Г., Егорова И.П., Булаткина Т.А. Состояние и перспективы развития минерально-сырьевой базы барита // Минеральные ресурсы России. Экономика и управление. 2017. - № 6. - C. 4-14.

5. Сырьевая база барита и перспективы ее развития / Г.Г. Ахманов, Н.Г. Васильев, Т.А. Булаткина, И.П. Егорова // Минеральные ресурсы России. Экономика и управление. - 1995. № 5. - C. 13-18.

6. Ведерников Н.Н., Аксенов Е.М. Социально-экономическая значимость и пути развития минерально-сырьевой базы нерудных полезных ископаемых // Разведка и охрана недр. 2003. - № 3. - C. 2-7.

7. Хатьков В.Ю. Состояние производства и потребления барита в России // Успехи современного естествознания. - 2004. № 8. - С. 141-142.

8. Доценко Н.П. Баритовая зависимость России. Миф или реальность? // Горный информационно-аналитический бюллетень. - 2005. - № 3. - С. 332-335.

9. Critical mineral resources of the United States - economic and environmental geology and prospects for future supply / K.J. Schulz, J.H. DeYoung, R.R. Seal, D.C. Bradley. - Reston, Virginia: U.S. Geological Survey, 2017. - 862 p. URL https://pubs.er.usgs.gov/publication/pp1802 (дата обращения 21.06.2021).

10. Study on the review of the list of Critical Raw Materials. Critical Raw Materials Factsheets. - Luxembourg: Publications Office of the European Union, 2017. - 515 p. URL: https://publications.europa.eu/en/publication-detail/-/publication/7345e3e8-98fc-11 e7-b92d-01aa75ed71a1/language-en (дата обращения 21.06.2021).

11. Analysis of strategic (critical) mineral resources situation in China and the U.S. and the EU / J.B. Chen, W.M. Huo, D.D. Feng et al. // Natural Resource Economics of China. - 2020. - V. 33. - № 8. P. 9-17.

12. Jiang Y., Wang T., Long T. Research on listing barite as a strategic mineral resource // Acta Geoscientica Sinica. - 2021. - V. 42. № 2. - P. 297-302.

13. Государственные доклады «О состоянии и использовании минерально-сырьевых ресурсов Российской Федерации». 2000-2019 гг. URL: https://www.mnr.gov.ru/docs/gosudarstvennye_doklady/o_sostoyanii_i_ispolzovanii_mineralno_syrevy kh_resursov_rossiyskoy_federatsii/ (дата обращения 21.06.2021).

14. Федеральная служба государственной статистики России. URL: https://gks.ru/emiss (дата обращения: 21.06.2021).

15. Федеральная таможенная служба России. URL: http://stat.customs.gov.ru/analysis (дата обращения: 21.06.2021).

16. A world of information. UNdata. URL: https://data.un.org/ (дата обращения: 21.06.2021)

17. Минерал. Информационно-аналитический центр «Минерал». URL http://www.mineral.ru/Center/index.html (дата обращения: 21.06.2021).

18. TrendEconomy. URL: dataexplorer (trendeconomy.ru) (дата обращения: 21.06.2021)

19. Касымов М.А. Формационные типы баритовых месторождений // Известия Кыргызского государственного технического университета им. И. Раззакова. - 2014. - № 33. - С. 108-112.

20. Войтов М.Д., Вети А.А. Анализ запасов Кызыл-Таштыгского полиметаллического месторождения, для обоснования строительства рудника // Вестник Кузбасского государственного технического университета. - 2012. - № 6 (94). - С. 45-48. публике Казахстан в экономических условиях стран Таможенного союза, а также рассмотреть возможность формирования новых импортных потоков баритового сырья из Китая, Индии и Лаоса.

21. Республика Бурятия. Инвестиционный портал Республики Бурятия. Минерально-сырьевой комплекс. URL: https://investburyatia.ru/index/investiczionnyie-predlozheniya/mineralnosyirevoj-kompleks/ (дата обращения: 21.06.2021).

22. Кузнецов Д.С. Баритовые месторождения Республики Коми и перспективы их освоения // Актуальные проблемы, направления и механизмы развития производительных сил Севера. - Сыктывкар: Коми республиканская типография, 2018. - С. 46-50.

23. Технико-экономические аспекты промышленного освоения Медведевского месторождения барита / В.И. Ноздря, Д.В. Саморуков, А.Н. Богачев, Н.В. Шегай // Горный информационно-аналитический бюллетень. - 2004. - № 3. - С. 332-336.

24. Месторождения остаточного типа Республики Башкортостан - основа для создания сырьевой базы «небурового» барита / Г.Г. Ахманов, Т.А. Булаткина, И.П. Егорова, И.А. Кузьмина, А.В. Кочергин, Н.Р. Галимов // Разведка и охрана недр. - 2019. - № 6. - С. 14-8.

25. Новый тип месторождений барита в Хакасии / Г.Г. Ахманов, Н.Г. Васильев, И. П. Егорова, Ф.И. Ходаковский, Е.С. Единцев // Отечественная геология. - 2007. - № 3. - С. 65-70.

26. Ахманов Г.Г., Егорова И.П., Васильев Н.Г. Дальний Восток новая перспективная на барит провинция // Разведка и охрана недр. - 2003. - № 3. - С. 24-28.

27. Upgradation of barite waste to marketable grade concentrate / R. Singh, B. Banerjee, K.K. Bhattacharyya, J.P. Srivastava // IMPC 2006 - Proceedings of 23rd International Mineral Processing Congress. - Istanbul: Turkey, 2006. - P. 2303-2307.

28. Recovery of lead and barite from the abandoned Ichmoul mine wastes in Algeria / N. Larachi, A. Bali, M. Ould Hamou, S. Bensaadi // Environmental Earth Sciences. - 2019. - V. 78. № 20. - Article no 601. DOI: 10.1007/s12665-019-8593-5.

29. Baranov B., Aloisi V., Degrachev A. Giant barite deposit mapped and the Derugin Basin (Okhotsk Sea) // Minerals of the Ocean integrated strategies - 2 Conference abstract. - St-Petersburg, 2004. - P. 214.

30. Современные геологические процессы и условия формирования баритовой залежи в котловине Дерюгина Охотского моря / А.С. Астахов, В.В. Ивин, В.Н. Карнаух, А.А. Коптев, Б.Я. Ли, Е.Н. Суховеев // Геология и геофизика. - 2017. - Т. 58. № 2. - C. 200-214.

31. Геология и полезные ископаемые дальневосточных морей России / С.И. Андреев, В.Е. Казакова, А.М. Иванова, А.Н. Смирнов // 70 лет в Арктике, Антарктике и Мировом океане. - СПб: ВНИИ геологии и минеральных ресурсов Мирового океана имени академика И.С. Грамберга, 2018. C. $444-454$

32. Lusty P.A.J., Murton B.J. Deep-ocean mineral deposits: metal resources and windows into earth processes // Elements. - 2018. V. 14. - № 5. - P. 301-306. DOI: 10.2138/gselements.14.5.301.

33. Metal extraction from deep-ocean mineral deposits / M.V. Zubkov, P.K. Plucinski, A.C.Y. Dartiguelongue, P.A.J. Lusty // Elements. 2018. - V. 14. - № 5. - P. 319-324. DOI: 10.2138/gselements. 14.5.319

34. Гершенкоп А.Ш., Хохуля М.С., Конторина Т.А. Разработка технологии гравитационно-магнитного обогащения баритсидеритовых руд месторождения Салланлатва // Горный информационно-аналитический бюллетень. - 2007. - № 10. C. $358-364$.

35. Высотин В.В. Разработка технологии флотации барита из золото-баритовой руды с использованием комплексного собирателя: дис. ... канд. техн. наук. - Иркутск, 2008. - 121 с.

36. Перейма А.А., Дубов Н.М., Черкасова В.Е. Буровой раствор на биополимерной основе для проводки скважин в условиях АВПД // Строительство нефтяных и газовых скважин на суше и на море. -2010 . - № 4. - С. 34-38.

37. Ермуханова С.Т., Лыгина Т.З. Основные технологии получения сульфата бария из природного барита // Actualscience. 2017. - T. 3. - № 3. - С. 98-100. 
38. Yermukhanova S.T., Khatsrinov A.I. The most important technologies of receiving barium sulfate from barite // European Science. - 2020. - № 6 (55). - P. 30-34.

39. Steele B.C.H., Heinzel A. Materials for fuel-cell technologies // Nature. - 2001. - № 414. - P. 345-352. DOI: 10.1038/35104620.
40. Sokolovskaya L.V., Kvyatkovskiy S.A., Semenova A.S. Barite phase formations during lead and zinc oxidized ores sintering // Integrated use of mineral raw materials. - 2018. - № 1 (304). P. 35-43.

Поступила 21.06.2021 2.

\section{Информация об авторах}

Боярко Г.Ю., доктор экономических наук, кандидат геолого-минералогических наук, профессор, отделение нефтегазового дела Инженерной Школы природных ресурсов Национальный исследовательский Томский политехнический университет

Хатьков В.Ю., начальник департамента, ПАО Газпром; соискатель отделения нефтегазового дела Инженерной школы природных ресурсов Национального исследовательского Томского политехнического университета 
UDC 339.13:553.689.2

\title{
CURRENT STATE OF PRODUCTION AND CONSUMPTION OF BARITE RAW MATERIALS IN RUSSIA
}

\author{
Grigory Yu. Boyarko1, \\ gub@tpu.ru
}

\author{
Vitaly Yu. Khatkov1,2, \\ V.Khatkov@adm.gazprom.ru \\ 1 National research Tomsk Polytechnic University, \\ 30, Lenin avenue, Tomsk, 634050, Russia. \\ 2 Gazprom PJSC, \\ 2, Pobedy square, St. Petersburg, 196143, Russia.
}

The relevance of the work is caused by the presence of periodic import dependence of Russia on barite raw materials.

Objective: study of the dynamics of commodity flows (production, import, export, consumption) of barite raw materials in Russia and on a global scale, its prices (world and Russian), the raw material base of barite in Russia and the prospects for its national production.

Methods: statistical, graphical, logical.

Results. Based on the analysis of the available information, it is concluded that barite mineral raw materials in Russia are a critical commodity product due to the limited production at a single field and the presence of significant volumes of barite imports at the border of the import dependence threshold. On the one hand, the small size of the Russian import barite commodity flow is easily ensured, on the other hand, it is not able to influence the prices and volumes of trade export-import flows of barite raw materials. The following measures are proposed to regulate the barite mining industry: the resumption of mining operations at the Khoylinsky group of barite deposits (Khoylinsky, Malokhoylinsky and Palnikskoe) in the Komi Republic and at the technogenic Urskoe field in the Kemerovo region; the organization of evaluation and exploration work at the Kuten-Buluksky, Mokhovsky, Karasugsky-ll and Yubileyny fields to the north of the decommissioned Tolcheinsky field in the Republic of Khakassia; priority searches for new deposits of barite raw materials should be organized near the existing transport infrastructure in the Alchano-Bikinskaya and Muravyevo-Amur baritone-bearing areas in the Primorsky Territory, on Anyuyskaya and Nizhne-Amurskaya areas in the Khabarovsk Territory, on Sakmarskaya Square in the Republic of Bashkortostan. It is proposed to maintain a stable import commodity flow of barite from permanent partners in the Republic of Kazakhstan in the economic conditions of the Customs Union countries, as well as to consider the possibility of forming new import flows of barite raw materials from India and Laos.

\section{Key words:}

Barite raw materials, import dependence, critical commodity product, mineral resource base, projects.

\section{REFERENCES}

1. Bearden S.D. Barite: World sources and the US market. Mining Engineering, 1997, vol. 49, no. 11, pp. 87-88.

2. Ellis R. Barite - a vital ingredient. Mining Magazine, 2004 vol. 188 , no. 5, pp. 38-39.

3. Petrov I.M. Trends and features of the development of the world and Russian markets for enriched types of non-metallic mineral raw materials. Mineral resources of Russia. Economics and Management, 2010, no. 6, pp. 68-71. In Rus.

4. Akhmanov G.G., Egorova I.P., Bulatkina T.A. State and prospects of development of the mineral resource base of barite. Mineral resources of Russia. Economics and Management, 2017, no. 6, pp. 4-14. In Rus.

5. Akhmanov G.G., Vasiliev N.G., Bulatkina T.A., Egorova I.P. Raw material base of barite and prospects for its development. Mineral resources of Russia. Economics and Management, 1995, no. 5, pp. 13-18. In Rus.

6. Vedernikov N.N., Aksenov E.M. Socio-economic significance and ways of development of the mineral resource base of non-metallic minerals. Prospect and protection of mineral resources, 2003, no. 3, pp. 2-7. In Rus.

7. Khatkov V.Yu. Sostoyanie proizvodstva i potrebleniya barita v Rossii [State of production and consumption of barite in Russia] Uspekhi sovremennogo estestvoznaniya, 2004, no. 8, pp. 141-142.

8. Dotsenko N.P. Russia's barite dependence. Myth or reality? Mining in formational and analytical bulletin, 2005, no. 3, pp. 332-335. In Rus.

9. Schulz K.J., DeYoung J.H., Seal R.R., Bradley D.C. Critical mineral resources of the United States - economic and environmental geology and prospects for future supply. Reston, Virginia, U.S. Geological Survey, 2017. 862 p. Available at: https://pubs. er.usgs.gov/publication/pp1802 (accessed 21 June 2021).
10. Study on the review of the list of critical raw materials. Critical raw materials factsheets. Luxembourg, Publications Office of the European Union. 2017. $515 \mathrm{p}$. Available at: https://publications.europa.eu/en/publication-detail/-/publication/ 7345e3e8-98fc-11e7-b92d-01aa75ed71a1 (accessed 21 June 2021).

11. Chen J.B., Huo W.M., Feng D.D. Analysis of strategic (critical) mineral resources situation in China and the U.S. and the EU. Natural Resource Economics of China, 2020, vol. 33, no. 8, pp. 9-17. In Chin.

12. Jiang Y., Wang T., Long T. Research on listing barite as a strategic mineral resource. Acta Geoscientica Sinica, 2021, vol. 42, no. 2, pp. 297-302. In Chin.

13. Gosudarstvennye doklady «O sostoyanii i ispolzovanii mineralnosyrevykh resursov Rossiyskoy Federatsii» [Ministry of Natural Resources and Environment of the Russian Federation. State report "State and use of mineral resources of the Russian Federation in 2000-2019]. Available at: https://www.mnr.gov.ru/docs/gosudarstvennye_doklady/o_sostoyanii_i_ispolzovanii_mineralno_ syrevykh_resursov_rossiyskoy_federatsii/ (accessed 21 June 2021).

14. Federalnaya sluzhba gosudarstvennoy statistiki Rossii. Bazy dannykh [Federal State Statistic Service. Databases]. Available at: https://gks.ru/emiss (accessed 21 June 2021).

15. Federalnaya tamozhennaya sluzhba Rossii. Bazy dannykh [Federal customs service. Databases]. Available at: http://stat.customs. gov.ru/analysis (accessed 21 June 2021).

16. UNdata. In world of information. Available at: https://data.un.org/ (accessed 21 June 2021)

17. Informatsionno-analiticheskiy tsentr "Mineral» [Information and analytical center «Mineral»]. Available at: http://www.mineral.ru/ Center/index.html (accessed 21 June 2021).

18. TrendEconomy. Annual statistics on international trade in goods. Available at: dataexplorer (trendeconomy.ru) (accessed 21 June 2021). 
19. Kasymov M.A. Formation types of barite deposits. Bulletin of the Kyrgyz State Technical University named after I. Razzakov, 2014, no. 33, pp. 108-112. In Rus.

20. Voitov M.D., Veti A.A. Analysis of the reserves of the KyzylTashtyg polymetallic deposit, to justify the construction of the mine. Bulletin of the Kuzbass state technical university, 2012, no. 6 (94), pp. 45-48. In Rus.

21. Respublika Buryativa. Investitsionny portal Respubliki Buryativa. Mineralno-syrevoy kompleks [Republic of Buryatia. Investmen portal of the Republic of Buryatia. Mineral-raw material complex] Available at: URL https://invest-buryatia.ru/index/investiczionnyie-predlozheniya/mineralno-syirevoj-kompleks/ (accessed 21 June 2021).

22. Kuznetsov D.S. Baritovye mestorozhdeniya Respubliki Komi i perspektivy ih osvoeniya [Barite deposits of the Komi Republic and prospects for their development]. Aktualnye problemy, napravleniya i mekhanizmy razvitiya proizvoditelnykh sil Severa [Actual problems, directions and mechanisms of development of the productive forces of the North]. Syktyvkar, Komi Republican Printing House, 2018. pp. 46-50.

23. Nozdrya V.I., Samorukov D.V., Bogachev A.N., Shegai N.V. Technical and economic aspects of the industrial development of the Medvedevsky barita deposit. Mining informational and analytical bulletin, 2004, no. 3, pp. 332-336. In Rus.

24. Akhmanov G.G., Bulatkina T.A., Egorova I.P., Kuzmina I.A., Kochergin A.V., Galimov N.R. Deposits of the residual type of the Republic of Bashkortostan are the basis for creating a raw material base of «non-drilling» barite. Exploration and protection of mineral resources, 2019, no. 6, pp. 14-18. In Rus.

25. Akhmanov G.G., Vasiliev N.G., Egorova I.P., Khodakovsky F.I. Edintsev E.S. A new type of barite deposits in the Republic of Khakassia. National Geology, 2007, no. 3, pp. 65-70. In Rus.

26. Akhmanov G.G., Egorova I.P., Vasiliev N.G. The Far East - a new promising province on barit. Prospect and protection of mineral resources, 2003, no. 3, pp. 24-28. In Rus.

27. Singh R., Banerjee B., Bhattacharyya K.K., Srivastava J.P. Upgradation of barite waste to marketable grade concentrate. IMPC 2006 - Proceedings of 23rd International Mineral Processing Congress. Istanbul, Turkey, 2006. pp. 2303-2307.

28. Larachi N., Bali A., Ould Hamou M., Bensaadi S. Recovery of lead and barite from the abandoned Ichmoul mine wastes in Algeria. Environmental Earth Sciences, 2019, vol. 78, no. 20. no article 601. DOI: 10.1007/s12665-019-8593-5

29. Baranov B., Aloisi V., Degrachev A. Giant barite deposit mapped and the Derugin Basin (Okhotsk Sea). Minerals of the Ocean - in tegrated strategies -2 Conference abstract. St-Petersburg, 2004. pp. 214.

\section{Information about the authors}

Grigory Yu. Boyarko, Dr. Sc., Cand. Sc., professor, National Research Tomsk Polytechnic University.

Vitaly Yu. Khatkov, department head, Gazprom PJSC; degree applicant, Oil and Gas Department of the Engineering School, National Research Tomsk.
30. Astahov A.S., Ivin V.V., Karnauh V.N., Koptev A.A., Li B.Ya., Suhoveev E.N. Modern geological processes and conditions for the formation of a barite deposit in the Deryugin basin of the Sea of Okhotsk. Geology and Geophysics, 2017, vol. 58, no. 2, pp. 200-214.

31. Andreev S.I., Kazakova V.E., Ivanova A.M., Smirnov A.N. Geologiya i poleznye iskopaemye dalnevostochnykh morey Rossii [Geology and minerals of the Far Eastern seas of Russia]. 70 let $v$ Arktike, Antarktike i Mirovom okeane [70 years in the Arctic, Antarctic and the World Ocean]. St. Petersburg, Institute of Geology and Mineral Resources of the World Ocean named after Academician I.S. Gramberg Publ., 2018. pp. 444-454.

32. Lusty P.A.J., Murton B.J. Deep-ocean mineral deposits: metal resources and windows into earth processes. Elements, 2018, vol. 14, no. 5, pp. 301-306. DOI: 10.2138/gselements.14.5.301.

33. Zubkov M.V., Plucinski P.K., Dartiguelongue A.C.Y., Lusty P.A.J. Metal extraction from deep-ocean mineral deposits. Elements, 2018, vol. 14, no. 5, pp. 319-324. DOI: 10.2138/gselements.14.5.319.

34. Gershenkop A.Sh., Khokhulya M.S., Kontorina T.A. Development of the technology of gravity-magnetic enrichment of barite-siderite ores of the Sallanlatva deposit. Mining informational and analytical bulletin, 2007, no. 10, pp. 358-364. In Rus.

35. Vysotin V.V. Razrabotka tekhnologii flotatsii barita iz zolotobaritovoy rudy s ispolzovaniem kompleksnogo sobiratelya. Dis. Kand. nauk [Development of technology for flotation of barite from gold-barite ore using an integrated collector. Cand. Diss.]. Irkutsk, 2008. $121 \mathrm{p}$.

36. Pereima A.A., Dubov N.M., Cherkasova V.E. Biopolymer-based drilling mud for drilling wells in WUA conditions. Construction of oil and gas wells on land and at sea, 2010, no. 4, pp. 34-38. In Rus.

37. Ermukhanova S.T., Lygina T.Z. Basic technologies for the production of barium sulfate from natural barite. Actualscience, 2017, vol. 3, no. 3, pp. 98-100. In Rus.

38. Yermukhanova S.T., Khatsrinov A.I. The most important technologies of receiving barium sulfate from barite. European Science, 2020, no. 6 (55), pp. 30-34 ture, 2001, no. 414, pp. 345-352. DOI: 10.1038/35104620.

40. Sokolovskaya L.V., Kvyatkovskiy S.A., Semenova A.S. Barite phase formations during lead and zinc oxidized ores sintering. Integrated use of mineral raw materials, 2018, no. 1 (304), pp. 35-43.

Received: 21 June 2021.
39. Steele B.C.H., Heinzel A. Materials for fuel-cell technologies. Na- 